\title{
Konten Kurikulum Akuntansi Perguruan Tinggi Dan Kesesuaiannya Dengan Standar Kompetensi Lulusan
}

\author{
Tasniem Fauzia ${ }^{1}$, Zalida Afni ${ }^{2}$, Elfitri Santi ${ }^{3 *}$ \\ 1Jurusan Akuntansi, Politeknik Negeri Padang \\ Email: tasniemfauzia89@gmail.com \\ 2Jurusan Akuntansi, Politeknik Negeri Padang \\ Email:zalida.afni@yahoo.com \\ 3Jurusan Akuntansi, Politeknik Negeri Padang \\ Email: elfitrisanti.pnp@gmail.com \\ *Corresponding Author
}

\begin{abstract}
Changing trends in business and finance have an impact on accounting learning and curriculum. This study aims to see how the college accounting curriculum produces competent graduates and their conformity with the IQF competency standards, the competencies needed to prepare graduates to enter the accounting profession and the competencies expected by users (employers). This study uses a mix-method with a sequential exploratory model (content analysis and descriptive statistical analysis). The results of this study show that colleges provide graduates with competencies in accounting, business, general competencies and other competencies that can support graduates' careers. The compatibility between graduates competencies based on the college accounting curriculum and the IQF competency standards has been appropriate, while the compatibility between graduates competencies with the professional organizations competency and user expectations competency has not been appropriate. In their curriculum, some college have included courses related to digital technology. We hoped there will be further harmonization and adjustment between the accounting curriculum and graduate competency standards to improve graduates work ability.
\end{abstract}

Keywords : Accounting curriculum, technological developments, KKNI, professional organizations competencies, user expectation competencies

\begin{abstract}
ABSTRAK
Perubahan tren di dunia bisnis dan keuangan membawa dampak kepada pembelajaran dan kurikulum akuntansi. Penelitian ini bertujuan untuk melihat bagaimana kurikulum akuntansi perguruan tinggi dalam menghasilkan lulusan yang kompeten dan kesesuaiannya dengan standar kompetensi KKNI, kompetensi yang diperlukan untuk mempersiapkan lulusan memasuki profesi akuntansi dan kompetensi-kompetensi yang menjadi harapan user (pemberi kerja). Penelitian ini menggunakan mixmethod dengan model sequential exploratory (analisis konten dan analisis statistik deskriptif). Hasil penelitian ini menunjukkan bahwa perguruan tinggi membekali lulusannya dengan kompetensi di bidang akuntansi, bisnis, kompetensi umum dan kompetensi lainnya yang dapat mendukung karir lulusan. Kesesuaian kompetensi lulusan akuntansi dengan standar kompetensi KKNI sudah sesuai sedangkan dengan kompetensi organisasi profesi dan kompetensi harapan user masih belum sesuai. Dalam kurikulumnya, beberapa perguruan tinggi juga telah memasukkan mata kuliah yang berkaitan dengan teknologi digital. Perguruan tinggi diharapkan dapat melakukan harmonisasi dan penyesuaian
\end{abstract}


lanjutan antara kurikulum akuntansi yang dimiliki dengan standar kompetensi guna meningkatkan kemampuan kerja lulusan.

Kata kunci: kurikulum akuntansi, perkembangan teknologi, KKNI, kompetensi organisasi profesi, kompetensi harapan user

\section{Pendahuluan}

Pendidikan merupakan suatu hal penting yang harus dimiliki oleh setiap orang dalam menjalani hidup. Kemajuan pendidikan suatu bangsa akan mendorong perkembangan suatu negara. Untuk itu, pemerintah terus meningkatkan dan mengembangkan sistem pendidikan yang ada di setiap jenjang pendidikan, termasuk di tingkat perguruan tinggi. Dibutuhkan perencanaan dan pengontrolan terhadap sistem yang digunakan dalam menjalankan pendidikan di perguruan tinggi, salah satunya adalah dengan merumuskan dan merancang kurikulum yang dapat menjadi acuan dan pedoman dalam menjalankan sistem pendidikan.

Menurut UU RI No. 20 tahun 2003 tentang Sistem Pendidikan Nasional, kurikulum adalah seperangkat rencana dan pengaturan mengenai tujuan, isi, dan bahan pelajaran, serta cara yang digunakan sebagai pedoman penyelenggaraan kegiatan pembelajaran untuk mencapai tujuan pendidikan tertentu. Penyusunan kurikulum disesuaikan dengan keadaan dan kemampuan setiap jenjang pendidikan dalam penyelenggaraan pendidikan. Penyusunanan kurikulum juga dapat disesuaikan dengan kompetensi yang dibutuhkan di lingkungan kerja. Masing-masing spesifikasi/jurusan tentu memiliki karakteristik tersendiri dalam perencanaan dan pengembangan konten dari kurikulum yang telah ditetapkan.

Jurusan akuntansi memiliki peranan penting dalam menghasilkan akuntan yang berkompeten dan dapat memenuhi kebutuhan di dalam dunia bisnis (harapan user). Pendidikan akuntansi harus mengikuti perubahan di bidang bisnis dan memberikan kurikulum yang akan memperkuat upaya akuntan untuk merespon secara memadai kebutuhan modern [16]. Perguruan tinggi di seluruh dunia, bagaimanapun, dituduh menghasilkan lulusan yang kekurangan soft skills yang dianggap penting untuk meningkatkan produktivitas dan inovasi di tempat kerja [13]. Hal ini berasal dari kelemahan dalam sistem pendidikan yang diterapkan (desain, isi dan struktur program sarjana).

Program studi wajib merumuskan kompetensi atau learning outcomes lulusannya dengan mengacu pada Kerangka Kualifikasi Nasional Indonesia (KKNI) dan rumusan kompetensi hasil kesepakatan yang melibatkan pihak yang terlibat dengan dunia kerja (organisasi profesi). Oleh karena itu kurikulum yang dimiliki oleh perguruan tinggi diharapkan mampu membantu lulusan untuk mengomunikasikan dan menyelesaikan masalah yang akan dihadapi di dunia kerja. Mempertimbangkan perkembangan dunia kerja bagi lulusan akuntansi, perguruan tinggi diharapkan mampu membekali mahasiswanya dengan keahlian spesifik yang dapat diperoleh melalui pengarahan kepada konsentrasi/spesifikasi tertentu yang mendukung minat dan kemampuan yang dimiliki oleh mahasiswa. Di sisi lain, lulusan akuntansi juga dituntut untuk memiliki knowledge base yang luas dan dapat dilatih sesuai dengan kebutuhan dunia kerja nantinya. Beberapa organisasi profesi akuntansi mengemukakan kerangka kompetensi untuk membantu relevansi topik yang akan dimasukkan perguruan tinggi dalam kurikulumnya seperti American Institute of 
Certified Public Accountans (AICPA), International Federation of Accountant (IFAC), Chartered Institute of Management Accountants (CIMA), danChartered Accountants Australia and New Zealand (CA ANZ). Penetapan kurikulum program studi akuntansi perlu memperhatikan perkembangan dunia bisnis, perkembangan teknologi informasi, dan internalisasi etika dalam membangun mentalitas akuntan yang berintegritas.

Setiap perguruan tinggi memiliki konten kurikulum jurusan akuntasi yang berbeda. Perbedaan tersebut menarik untuk diamati dan dapat dijadikan pedoman untuk peningkatan kualitas dan perbaikan kurikulum di masa yang akan datang. Penelitian mengenai pengembangan kurikulum telah dilakukan oleh beberapa peneliti. Penelitian yang telah dilakukan oleh peneliti terdahulu mengenai kurikulum akuntansi di perguruan tinggi dilihat dari berbagai aspek, seperti pandangan akuntan dalam industri dan profesi di Yordania [20], internasionalisasi kurikulum pada perguruan tinggi di Australia [7], dan kurikulum akuntansi dengan permintaan pasar di Yunani [16]. Kurikulum juga dilihat berdasarkan daftar kompetensi inti American Institute of Certified Public Accountans/AICPA [3], serta dilakukan evaluasi dan analisis kurikulum 30 perguruan tinggi terbaik di Amerika Serikat [1; 17].

Dari penelitian terdahulu, penelitian yang dilakukan hanya melihat kesesuaian antara kurikulum akuntansi dengan salah satu standar kompetensi, seperti kompetensi yang menjadi harapan user atau kompetensi organisasi profesi. Belum ditemukan penelitian mengenai perbandingan konten kurikulum yang diterapkan perguruan tinggi dari berbagai wilayah. Hal ini membuat peneliti ingin melakukan penelitian mengenai topik ini. Pada penelitian ini dilihat kesesuaian kurikulum akuntansi dengan tiga standar kompetensi, yakni kompetensi organisasi profesi, kompetensi harapan user, dan standar kompetensi KKNI pada beberapa perguruan tinggi dari wilayah Amerika, Eropa, Asia dan Australia. Penelitian dilakukan melalui analisis konten terhadap kurikulum akuntansi dan kemudian dilakukan analisis statistik deskriptif untuk menguantitatifkan hasil analisis konten yang telah didapatkan.

Penelitian ini bertujuan untuk mengetahui bagaimana kurikulum akuntansi pada perguruan tinggi di Amerika, Eropa, Asia, dan Australia dalam menghasilkan lulusan yang kompeten dan mampu menghadapi perkembangan dunia bisnis dan keuangan. Peneliti ingin melihat keunikan dari program akuntansi yang dijalankan oleh berbagai perguruan tinggi yang dapat membawa perguruan tinggi tersebut menjadi unggulan dalam bidang akuntansi. Kemudian, penelitian ini juga bertujuan untuk mengetahui kesesuaian antara kompetensi lulusan akuntansi pada perguruan tinggi yang ada di Amerika, Eropa, Asia, dan Australia dengan KKNI, kerangka kerja yang dikeluarkan oleh organisasi profesi, dan kompetensi yang menjadi harapan user. Oleh karena itu, penelitian ini akan menganalisis dan membandingkan konten kurikulum yang dimiliki oleh jurusan akuntansi pada beberapa perguruan tinggi di Amerika, Eropa, Asia dan Australia.

Penelitian ini diharapkan dapat menjadi pertimbangan dan masukan dalam perbaikan dan pengembangan kurikulum akuntansi agar dapat menghasilkan lulusan akuntansi yang kompeten dan mampu bersaing menghadapi perkembangan dunia bisnis dan keuangan. Selain itu, penelitian ini juga diharapkan dapat menambah literasi di bidang akuntansi serta dapat menjadi bahan rujukan bagi peneliti yang ingin meneliti di bidang yang sama. 


\section{Tinjauan Pustaka}

\section{Kurikulum}

Menurut UU RI No. 20 tahun 2003 [23], kurikulum adalah seperangkat rencana dan pengaturan mengenai tujuan, isi, dan bahan pelajaran, serta cara yang digunakan sebagai pedoman penyelenggaraan kegiatan pembelajaran untuk mencapai tujuan pendidikan tertentu. Kurikulum menurut (10) memiliki pengertian dalam empat dimensi, di mana dimensi tersebut saling berhubungan. Keterkaitan keempat dimensi tersebut dapat digambarkan sebagai berikut.

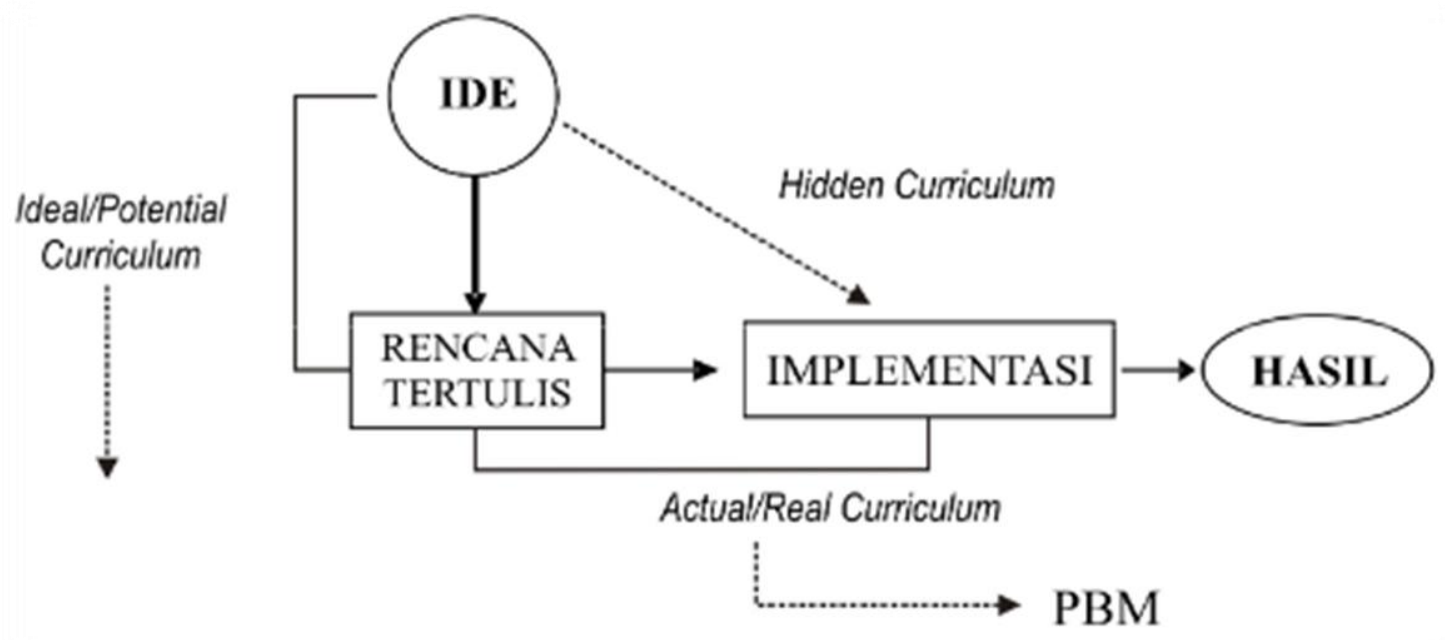

\section{Gambar 1. Dimensi Kurikulum}

Sumber: Hasan, 1988

Dari gambar di atas dapat dilihat bahwa kurikulum merupakan suatu ide. Ide tersebut kemudian diwujudkan menjadi suatu rencana tertulis. Pelaksanaan dari rencana tertulis menjadikan kurikulum sebagai suatu kegiatan atau realita. Dan konsekuensi dari suatu kegiatan akan menjadi hasil dari kurikulum. Keberadaan suatu kurikulum sangat penting bagi lembaga pendidikan karena berkaitan dengan tujuan dari lembaga tersebut. Kurikulum berperan dalam pencapaian tujuan pendidikan, yakni sebagai sarana untuk mentrasmisikan nilai-nilai yang telah ada dan mengembangkan suatu hal baru yang dapat membantu dan memenuhi kebutuhan masyarakat. Oleh karena itu, keberadaan kurikulum dalam suatu lembaga pendidikan akan sangat menentukan dan berpengaruh pada kompetensi lulusan yang dihasilkan oleh lembaga pendidikan tersebut. Untuk itu, dalam penelitian ini kurikulum akuntansi perguruan tinggi menjadi objek utama untuk melihat bagaimana perguruan tinggi dari berbagai wilayah menghasilkan lulusan yang kompeten.

\section{Kurikulum Akuntansi berdasarkan KKNI}

Kurikulum perguruan tinggi dikembangakan dan dilaksanakan berbasis pada kompetensi. Kerangka dasar dan struktur kurikulum pada pendidikan tinggi dikembangkan oleh perguruan tinggi untuk setiap program studi yang dimiliki perguruan tinggi. Pengembangan tersebut melibatkan pihak internal maupun pihak 
eksternal seperti organisasi profesi, instansi pemerintah, dan kelompok ahli yang relevan melalui forum program studi sejenis.

Berdasarkan Permendikbud No. 73 tahun 2013 tentang Penerapan Kerangka Kualifikasi Nasional Indonesia Bidang Pendidikan Tinggi [19], kurikulum yang berlaku pada pendidikan tinggi adalah kurikulum yang berbasis Kerangka Kualifikasi Nasional Indonesia (KKNI). KKNI merupakan kerangka perjenjangan kualifikasi yang menyandingkan, menyetarakan, dan mengintegrasikan capaian pembelajaran dari jalur pendidikan nonformal, pendidikan informal, dan/atau pengalaman kerja ke dalam jenis dan jenjang pendidikan tinggi. Penyesuaian dan penyetaraan sistem pendidikan di Indonesia dengan sistem pendidikan di negara-negara lain dilakukan melalui KKNI. Dalam pembentukannya, tim pembentuk KKNI memperhatikan perkembangan kerangka kualifikasi negara-negara lain dengan keterlibatan Indonesia dalam konvensi internasional seperti GATS (General Agreement on Trade in Services), WTO (World Trade Organization), dan AFTA (Asean Free Trade Area). Hal ini bertujuan agar kualifikasi yang dikeluarkan oleh KKNI dapat sepadan dan sebanding dengan kualifikasi yang dihasilkan negara lain.

Pada penelitian ini, KKNI menjadi salah satu indikator dalam melihat bagaimana kurikulum perguruan tinggi menghasilkan lulusan yang kompeten agar dapat bersaing di dunia kerja. Terdapat enam parameter atau substansi pokok kompetensi lulusan yang akan dilihat keberadaannya dalam kurikulum akuntansi masing-masing perguruan tinggi. Enam parameter tersebut diantaranya ilmu pengetahuan (science), pengetahuan (knowledge), pengetahuan prakatis (know-how), keterampilan (skill), afeksi (affection) dan kompetensi (competency).

\section{Kompetensi Akuntansi Berdasarkan Organisasi Profesi}

Organisasi profesi merupakan salah satu pihak yang memiliki peran aktif dalam membantu meningkatkan perkembangan dan kemampuan suatu profesi. Salah satu langkah yang dilakukan oleh organisasi profesi adalah dengan mengeluarkan kerangka kerja/framework. Kerangka kerja berguna untuk menentukan kompetensi-kompetensi yang dibutuhkan lulusan untuk memasuki profesi tertentu sesuai dengan bidang yang menjadi fokusnya. Kerangka kerja yang dikeluarkan oleh organisasi profesi dapat menjadi salah satu indikator dalam melihat kompetensi lulusan berdasarkan pada kompetensi yang dibutuhkan oleh profesi akuntansi di masa depan.

Beberapa organisasi profesi akuntansi, seperti American Institute of Certified Public Accountans (AICPA), International Federation of Accountant (IFAC), Chartered Institute of Management Accountants (CIMA), dan Chartered Accountants Australia and New Zealand (CA ANZ) mengemukakan kerangka kompetensi untuk membantu relevansi topik yang akan dimasukkan perguruan tinggi dalam kurikulumnya. AICPA mengeluarkan kerangka yang dikembangkan oleh pendidik dan profesional akuntansi untuk menentukan serangkaian kompetensi berbasis keterampilan yang dibutuhkan mahasiswa yang memasuki profesi akuntansi [2]. Kerangka tersebut adalah The AICPA Pre-certification Core Competency Framework yang berisi tiga kompetensi, yakni accounting competencies, business competencies dan professional competencies.

AICPA bersama dengan CIMA pada tahun 2012 mendirikan penunjukan CGMA (Chartered Global Management Accountant) untuk memberikan tingkat sumber daya dan pengakuan yang baru bagi para anggota. Silabus CIMA mengacu pada CGMA principle dan CGMA competency framework. Kerangka Kompetensi CGMA dirancang 
untuk membantu akuntan manajemen dan pemberi kerja mereka memahami persyaratan pengetahuan dan menilai keterampilan yang dibutuhkan untuk peran saat ini dan yang diinginkan [6]. Kerangka kerja ini didukung oleh kebutuhan akan objektivitas, integritas, perilaku etis dan mencakup komitmen untuk terus memperoleh keterampilan dan pengetahuan baru.

Dalam rangka memenuhi kompetensi pengetahuan untuk akuntan profesional, IFAC menerbitkan Handbook of International Education Pronouncements 2017 edition. Melalui International Accounting Education Standards Board (IAESB) dirancang International Education Standard (IES) yang memuat kerangka dasar untuk memperoleh kualifikasi sebagai akuntan profesional [11]. Kemudian CA ANZ juga mengeluarkan sebuah kerangka kerja/framework yang dikenal dengan CA Capability Model. CA Capability Model merupakan kerangka kerja yang dirancang untuk membantu profesi akuntan agar dapat fleksibel dan beradaptasi dengan perubahan yang terjadi di masa depan [5]. Diakui bahwa kerangka kerja ini perlu dilengkapi dengan keterampilan, pengetahuan, dan kompetensi perilaku yang lebih spesifik bergantung pada konteks atau variasi dalam desain pekerjaan.

Dalam penelitian ini, kerangka kerja yang dikeluarkan oleh AICPA, CIMA, IFAC, dan CA ANZ dijadikan salah satu indikator dalam melihat kesesuaian kompetensi lulusan akuntansi (melalui kurikulum akuntansi) dengan kompetensi yang diperlukan menurut organisasi profesi.

\section{Kompetensi harapan user}

Low [15] meneliti ekspektasi pengusaha akuntansi dari lulusan akuntansi yang ideal, temuannya menunjukkan bahwa, dalam hal keterampilan teknis, pengusaha memerlukan setidaknya pemahaman yang baik tentang keterampilan akuntansi mendasar. Mengingat fungsi yang terkait dengan perguruan tinggi, mereka harus menanggapi tuntutan bisnis tersebut. Akibatnya, mereka harus mendidik siswa mereka mengikuti kurikulum yang sesuai dengan kebutuhan pasar tenaga kerja. Kesesuaian ini akan memungkinkan peningkatan kemampuan kerja lulusan universitas [16]. Namun, di samping itu lebih banyak yang diharapkan secara teknis dari lulusan universitas karena keterampilan teknis yang perlu dipelajari di tempat kerja. Sebaliknya, pemberi kerja lebih menekankan pada keterampilan umum dan nonteknis yang dimiliki lulusan. Pengusaha juga sangat menekankan pada keterampilan mendengarkan, keterampilan kerja tim, keterampilan memecahkan masalah, dan ambisi / motivasi yang dirasakan. Selain itu, kecerdasan emosional calon tenaga kerja menjadi pertimbangan penting lainnya. Perkembangan teknologi dan informasi dalam bisnis dan keuangan juga menuntut pembaharuan dalam menghasilkan lulusan akuntansi yang berkompeten dan mampu menghadapi kemajuan teknologi.

\section{Literatur review}

Penelitian mengenai kurikulum akuntansi pada Perguruan Tinggi dilakukan [20] dengan menguji pandangan akuntan baik dalam industri maupun profesi mengenai konten mata kuliah akuntansi pada tingkat sarjana yang ditawarkan oleh Departemen Akuntansi di Yarmouk University, Yordania. Hasil penelitiannya adalah isi dari mata kuliah akuntansi relatif sesuai dengan kebutuhan dan persyaratan pekerjaan di Yordania. Namun, ada celah sempit antara konten kursus yang ditawarkan sehingga diperlukan beberapa revisi untuk isi mata kuliah tertentu. 
Penelitian yang dilakukan oleh [18] menyoroti bahwa perubahan kurikulum yang melibatkan keterlibatan industri sebagai bagian dari pembelajaran inovatif dan kegiatan penilaian dalam suatu program studi, membutuhkan sumber daya dan dukungan yang substansial bagi akademisi yang bertanggung jawab untuk melaksanakan perubahan. [3] meninjau keterampilan kompetensi inti yang ada di dalam daftar AICPA, dan mendiskusikan bagaimana memasukkannya ke dalam mata kuliah "Selected Topic in Accounting". Andre \& Smith mengemukakan dengan memasukkan kompetensi inti AICPA ke dalam mata kuliah, dapat mengembangkan banyak kompetensi utama yang digariskan oleh AICPA sebagai kompetensi penting bagi akuntan.

Penelitian yang dilakukan oleh [16] menguji apakah kurikulum akuntansi sesuai dengan permintaan bisnis di Yunani dengan melakukan survey pada mahasiswa, dosen/profesor dan pengusaha. Hasil yang diperoleh berupa bukti bahwa semua kelompok memiliki persepsi yang berbeda terhadap kurikulum. Berdasarkan hasil survey, jurusan akuntansi harus berfokus pada pengetahuan dan keterampilan pada keterampilan komunikasi lisan dan tertulis, keterampilan berbicara di depan umum, kemampuan berpikir kritis, kemampuan bekerja di bawah tekanan, dan kesesuaian pribadi dengan citra perusahaan.

Penelitian [1] menganalisis mata kuliah yang ada di jurusan akuntansi dan bisnis dari tiga puluh program akuntansi yang diidentifikasi oleh The Accounting Degree Review. Penelitian ini dilakukan untuk mengembangkan profil dari program akuntansi terbaik, membandingkan program akuntansi perguruan tinggi sektor publik dan privat, dan melihat perbedaan program yang memiliki akreditasi akuntansi dan akreditasi bisnis.

Dari penelitian yang dilakukan oleh peneliti sebelumnya dapat dilihat penelitian mengenai pengembangan kurikulum yang dikaitan dengan berbagai aspek seperti pandangan akuntan dalam industri dan profesi di Yordania [20], penerapan program WIL di Australia [18], dan permintaan pasar di Yunani [16]. Kurikulum juga dilihat berdasarkan daftar kompetensi inti AICPA [3], serta dilakukan evaluasi dan analisis kurikulum 30 perguruan tinggi terbaik di Amerika Serikat [1]. Sejauh ini, peneliti belum menemukan penelitian mengenai penerapan kurikulum akuntansi pada perguruan tinggi diberbagai wilayah (Amerika, Eropa, Asia dan Australia) dalam menghasilkan kompetensi lulusan yang dilihat kesesuaiannya dengan standar kompetensi berdasarkan KKNI, harapan user, dan organisasi profesi dalam menghadapi perkembangan tren bisnis dan keuangan. Penggunaan tiga standar kompetensi tersebut pada penelitian ini, dapat dilihat dan dibandingkan kesesuaian masing-masing standar dengan kurikulum akuntansi yang ada di berbagai wilayah.

\section{Metode Penelitian Desain penelitian}

Penelitian ini akan mengkombinasikan dua tipe atau metode pendekatan (kualitatif dan kuantitatif) yang secara simultan melalui suatu penerapan pendekatan penelitian alternatif, yaitu metode penelitian campuran atau mixed-method research [8]. Penelitian akan dilakukan melalui dua tahap, yakni tahap pertama penulis menggunakan 
pendekatan kualitatif. Kemudian pada tahap kedua, dilanjutkan dengan pendekatan kuantitatif.

\section{Data dan sampel}

Pada penelitian ini, sampel yang digunakan berupa kurikulum akuntansi dari 60 perguruan tinggi. Perguruan tinggi tersebut terdiri dari 25 perguruan tinggi yang berada di Amerika, 12 peguruan tinggi yang berada di Eropa, 12 perguruan tinggi yang berada di Asia, dan 11 perguruan tinggi yang berada di Australia. Pemilihan sampel ini didasarkan pada universitas yang telah di-ranking berdasarkan top accounting and finance program dari US News Ranking dan QS Ranking pada wilayah Amerika, Eropa, Asia, dan Australia. Data kurikulum akuntansi masing-masing perguruan tinggi diperoleh dari website resmi perguruan tinggi. Data standar kompetensi KKNI, organisasi profesi (AICPA, IFAC, CIMA, CA ANZ) juga diperoleh dari website resmi organisasi. Data kompetensi yang menjadi harapan user diperoleh dengan mengadopsi hasil penelitian yang dilakukan oleh [16].

\section{Metode analisis data}

Penelitian akan dilakukan melalui dua tahap, yakni tahap pertama data akan dianalisis menggunakan pendekatan atau metode kualitatif. Kurikulum akuntansi dan standar kompetensi lulusan berdasarkan KKNI, kerangka kerja organisasi profesi dan harapan userdianalisis menggunakan analisis konten dengan software Nvivo. Dalam melakukan analisis konten, dilakukan identifikasi terhadap muatan kurikulum akuntansi dan muatan standar kompetensi KKNI, kerangka kerja masing-masing organisasi profesi, serta kompetensi harapan user. Kemudian dilakukan pengelompokan untuk memperoleh kode yang digunakan dalam proses coding. Coding merupakan kegiatan memberikan kode pada kata, frasa, kalimat atau paragraf yang mewakili kode tersebut. Kode yang digunakan umumnya adalah konsep atau istilah yang memiliki makna tertentu.Setelah dilakukan coding, selanjutnya dilakukan pengecekan terhadap keberadaan kode dalam data sampel. Pengecekan ini dilakukan untuk melihat kesesuaian antara data kurikulum dengan data kompetensi. Hasil yang didapat untuk masing-masing kode di-export ke dalam microsoft excel. Hasil tersebut kemudian disatukan dan dilakukan perhitungan terhadap jumlah references yang ada pada masing-masing kode.

Setelah diperoleh hasil analisis konten, dilanjutkan analisis data menggunakan metode kuantitatif, yakni menggunakan analisis statistik deskriptif. Statistik deskriptif adalah statistik yang digunakan untuk menganalisis data dengan cara mendeskripsikan atau menggambarkan data yang telah terkumpul sebagaimana adanya tanpa bermaksud membuat kesimpulan yang berlaku untuk umum atau generalisasi [22]. Statistik deskriptif melibatkan transformasi data mentah ke dalam bentuk yang akan memberikan informasi untuk menggambarkan sekumpulan faktor dalam suatu situasi [21]. Analisis statistik deskriptif dilakukan menggunakan program SPSS. Analisis statistik deskriptif 
dilakukan untuk melihat persentase dan rata-rata kesesuaian kurikulum akuntansi dengan standar kompetensi KKNI, organisasi profesi dan harapan user. Penerapan metode campuran seperti ini diharapkan dapat memberikan pemahaman yang lebih luas mengenai kurikulum yang diterapkan di perguruan tinggi dan kompetensi lulusan yang dibutuhkan untuk menghadapi perkembangan tren di dunia bisnis dan keuangan.

\section{Hasil dan Pembahasan Analisis data}

\section{Kurikulum akuntansi perguruan tinggi}

Analisis awal yang dilakukan adalah dengan mengidentifikasi definisi kurikulum dari undang-undang, pendapat para ahli, dokumen KKNI, dan kerangka kompetensi organisasi profesi. Berdasarkan analisis yang dilakukan, diperoleh beberapa poin/codes yang dapat mengacu pada definisi kurikulum, yakni idea, set of plans, foundation skills and knowledge, guidelines for implementing learning activities, and outcome. Kode ini dapat dijadikan acuan dalam mengidentifikasi muatan kurikulum akuntansi perguruan tinggi. Identifikasi muatan kurikulum akuntansi dilakukan untuk melihat bagaimana kurikulum akuntansi perguruan tinggi dalam menghasilkan lulusan yang berkompeten. Identifikasi muatan kurikulum akuntansi dilakukan dengan pengelompokan mata kuliah berdasarkan kesamaan bidang/fokus, makna dan tujuannya. Pengelompokan yang dilakukan bertujuan untuk mendapatkan keyword yang sesuai dengan definisi kurikulum dan identifikasi muatan kurikulum. Hasil identifikasi kurikulum akuntansi perguruan tinggi dalam menghasilkan lulusan, dapat dikelompokan ke dalam bagian-bagian berikut ini.

1. Accounting Core

Accounting core merupakan kelompok mata kuliah yang memiliki fokus utama dalam bidang akuntansi. Mata kuliah tersebut antara lain, seperti akuntansi keuangan (financial accounting), akuntansi manajemen (management accounting), sistem informasi akuntansi (accounting information system), pajak (taxation), dan lain-lain

2. Business Core

Business core merupakan kelompok mata kuliah yang memiliki fokus utama dalam bidang bisnis dan keuangan. Mata kuliah tersebut antara lain, seperti analisis bisnis (business analysis), hukum bisnis (business law), managemen, ekonomi, dan lain-lain.

3. General Course

General course merupakan kelompok mata kuliah yang bersifat umum, yang dipelajari oleh mahasiswa akuntansi maupun mahasiswa jurusan lain. Mata kuliah tersebut antara lain, seperti matematika, statistik, bahasa, metodologi penelitian, teknologi informasi, dan lain-lain.

4. Other Course

Other course merupakan kelompok mata kuliah yang terdiri dari berbagai mata kuliah dengan tujuan untuk mendukung mahasiswa dalam pengembangan karir setelah lulus kuliah. Mata kuliah tersebut antara lain, seperti entrepreneurship, 
psikologi kerja, mata kuliah praktik yang memberikan pengalaman kepada mahasiswa (internship, case competition, project management), dan lain-lain.

Hasil dari pengelompokkan muatan kurikulum ini digunakan sebagai kode dalam melakukan coding pada kurikulum akuntansi perguruan tinggi. Selain dengan pengelompokkan, kode juga diperoleh melalui word frequency. Dari perhitungan word frequency yang dilakukan, diperoleh kata-kata yang paling banyak terdapat dalam kurikulum akuntansi. Kata yang banyak terdapat dalam kurikulum akuntansi memiliki makna bahwa keberadaan kata tersebut penting dalam kurikulum sehingga dapat dipertimbangkan untuk menjadi kode dalam mengidentifikasi muatan kurikulum. Berikut merupakan hasil word frequency pada kurikulum akuntansi.

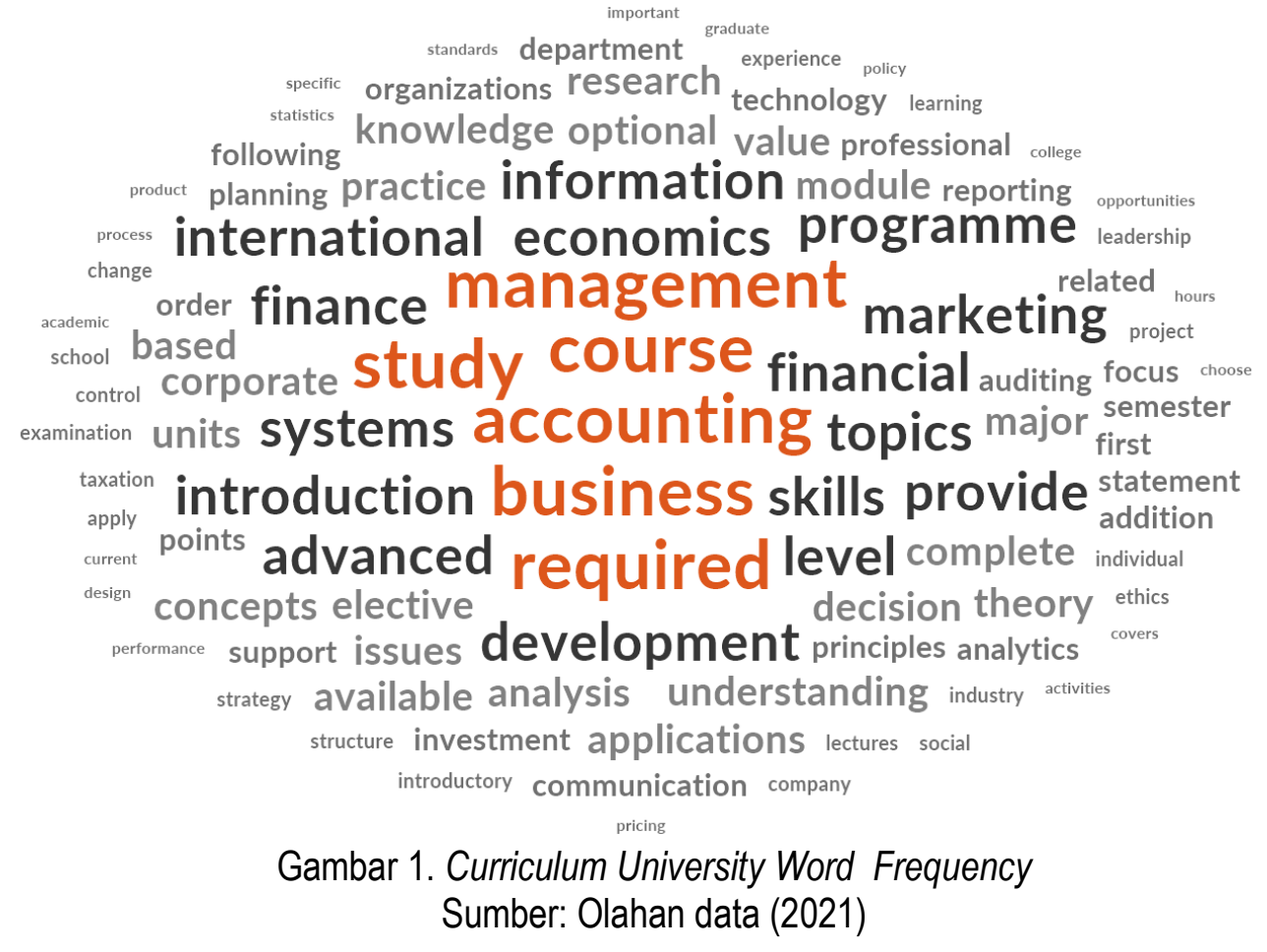

Setelah dilakukan coding dan memperoleh kode untuk kurikulum akuntansi, selanjutnya dilakukan pemeriksaan terhadap keberadaan kode dalam kurikulum akuntansi seluruh perguruan tinggi. Pemeriksaan ini dilakukan dengan menggunakan text search.Hasil yang didapatkan dari text search kemudian di-export ke dalam microsoft excel. Setelah itu, disatukan dan dilakukan perhitungan jumlah mata kuliah yang ada dalam masing-masing kelompok. Kemudian dilakukan perhitungan keberadaan mata kuliah dalam kurikulum akuntansi perguruan tinggi terhadap seluruh mata kuliah.

\section{Kompetensi berdasarkan KKNI}

KKNI menjadi salah satu indikator dalam melihat bagaimana kurikulum perguruan tinggi menghasilkan lulusan yang berkompeten agar dapat bersaing di dunia kerja. Untuk melihat kesesuaian KKNI dengan kurikulum akuntansi perguruan tinggi, penulis melakukan analisis dengan melakukan coding terhadap data kompetensi lulusan KKNI. Penulis menggunakan enam parameter atau substansi pokok kompetensi lulusan yang dikeluarkan KKNI sebagai kode.Setelah dilakukan coding dan memperoleh kode untuk 
kompetensi lulusan berdasarkan KKNI, selanjutnya dilakukan pemeriksaan terhadap keberadaan kode dalam kurikulum akuntansi seluruh perguruan tinggi. Pemeriksaan ini dilakukan dengan menggunakan fitur text search. Hasil yang didapatkan dari text search kemudian di-export ke dalam microsoft excel. Setelah itu, hasil perhitungan disatukan dan dilanjutkan dengan pengolahan data secara kuantitatif.

\section{Kompetensi organisasi profesi}

Kerangka kerja yang dikeluarkan oleh organisasi profesi dapat dijadikan salah satu indikator dalam melihat kesesuaian kompetensi lulusan akuntansi (melalui kurikulum akuntasi) dengan kompetensi yang diperlukan menurut organisasi profesi. Kompetensi yang digunakan sebagai indikator penilaian didapat melalui penyatuan kerangka kerja dari beberapa organisasi profesi, diantaranya adalah kerangka kerja dari AICPA, IFAC, CIMA, dan CA ANZ. Dari hasil identifikasi kerangka kerja masingmasing organisasi profesi, kompetensi yang diperlukan lulusan berdasarkan kerangka kerja organisasi profesi dapat dikelompokan ke dalam bagian-bagian berikut ini.

\section{Accounting Competencies}

Accounting Competencies merupakan kelompok kompetensi yang memiliki fokus utama pada kemampuan teknis dalam bidang akuntansi. Identifikasi kompetensi akuntansi dalam kurikulum akuntansi perguruan tinggi dapat dilihat dengan keberadaan mata kuliah yang berkaitan dengan kompetensi ini. Berikut mata kuliah yang termasuk dalam kelompok kompetensi akuntansi.
a. Accounting information systems
b. Audit and assurance
c. Financial accounting
d. Management accounting
e. Research
f. Risk assessment and analysis
g. Taxation

\section{Business Competencies}

Business Competencies merupakan kelompok kompetensi yang memiliki fokus pada keterampilan dalam menggunakan pengetahuan tentang bisnis untuk mengubah data menjadi wawasan. Hal ini memungkinkan untuk mengevaluasi posisi strategis, penyelarasan model bisnis dengan strategi, kinerja dan peluang untuk masa depan. Identifikasi kompetensi bisnis dalam kurikulum akuntansi perguruan tinggi, dapat dilihat dengan keberadaan mata kuliah yang berkaitan dengan kompetensi ini, diantaranya adalah sebagai berikut.
a. Business relation
b. Customer perspective
c. Global and industry perspective
d. Management

\section{Digital Skills}

Digital Skills merupakan kelompok yang berkaitan dengan keterampilan digital. Keterampilan ini sangat penting untuk dimiliki dalam menghadapi perkembangan dunia bisnis dan keuangan pada zaman sekarang. Jika ingin tetap relevan, lulusan harus mampu mengikuti kemajuan teknologi dan mampu mengelola serta memandu fungsi keuangan di dunia digital. Identifikasi terhadap keterampilan digital dalam kurikulum akuntansi perguruan tinggi 
dapat dilihat dengan keberadaan mata kuliah yang berkaitan dengan keterampilan ini, diantaranya adalah sebagai berikut.

a. Data analysis

b. Digital fluency

4. Professional Competencies

Professional Competencies merupakan kelompok yang berkaitan dengan keterampilan, sikap dan perilaku profesional akuntansi. Kemampuan profesional meliputi kemampuan berkomunikasi secara efektif dan kemampuan untuk berkolaborasi. Kemampuan berkomunikasi dapat digunakan untuk mempengaruhi keputusan, tindakan dan perilaku semua orang yang ada dalam organisasi. Sementara itu, kemampuan untuk berkolaborasi sangat diperlukan dalam kerja kelompok ataupun pekerjaan yang berkaitan dengan pihak lain. Kedua keterampilan di atas merupakan kemampuan penting yang harus dimiliki oleh lulusan akuntansi.

Identifikasi terhadap kompetensi profesional dalam kurikulum akuntansi perguruan tinggi, dapat dilihat dari keberadaan mata kuliah yang berkaitan dengan keterampilan ini, diantaranya adalah sebagai berikut.
a. Collaboration
b. Communication
c. Critical thinking
d. Decision-making
e. Ethical conduct
f. Leadership
g. Professional behavior
h. Project management

Hasil dari pengelompokkan ini digunakan sebagai kode dalam melakukan coding pada kompetensi organisasi profesi. Setelah dilakukan coding, selanjutnya dilakukan pengecekan terhadap keberadaan kode dalam kurikulum akuntansi seluruh perguruan tinggi. Pengecekan ini dilakukan dengan menggunakan fitur text search. Hasil yang didapatkan dari text search kemudian di-export ke dalam microsoft excel. Setelah itu, hasil perhitungan disatukan dan dilanjutkan dengan pengolahan data secara kuantitatif.

\section{Kompetensi harapan user}

Kompetensi lulusan akuntansi yang dituntut oleh dunia usaha mengalami banyak perubahan seiring dengan perkembangan yang terjadi dalam dunia bisnis dan keuangan. Mengingat fungsinya, perguruan tinggi harus menanggapi tuntutan tersebut. Ini mengharuskan perguruan tinggi mempunyai kurikulum yang dapat mengikuti perkembangan bisnis dan keuangan sehingga dapat menghasilkan lulusan yang sesuai dengan harapan user dan kebutuhan pasar tenaga kerja. Kesesuaian ini akan memungkinkan peningkatan kemampuan kerja dari lulusan perguruan tinggi.

Oleh karena itu, dilakukan identifikasi terhadap kompetensi-kompetensi yang menjadi harapan user. Kompetensi-kompetensi tersebut dapat dijadikan indikator dalam melihat kesesuaian kompetensi lulusan akuntansi (melalui kurikulum akuntasi) dengan kompetensi yang menjadi harapan user. Pada penelitian ini, penulis mengadaptasi kompetensi yang menjadi harapan user berdasarkan hasil penelitian 
dari [16]. Mandilas menguji apakah kurikulum akuntansi sesuai dengan permintaan bisnis melalui survei yang dilakukan pada pengusaha, dosen/profesor dan mahasiswa tentang kurikulum pendidikan tinggi. Mandilas juga memberikan masukan empiris dan kerangka kerja untuk menilai isi program akuntansi yang ada dan mereformasi kurikulum untuk membangun pengetahuan dan keterampilan yang dibutuhkan dalam pendidikan akuntansi. Oleh karena itu, penulis mengidentifikasi kompetensi yang menjadi harapan user melalui pengelompokkan mata kuliah dan softskill seperti berikut ini.

Tabel 1. Pengelompokan Kompetensi Harapan User

\begin{tabular}{|c|l|l|}
\hline No & Kelompok & Kode \\
\hline 1. & $\begin{array}{l}\text { Basic Accounting } \\
\text { Course }\end{array}$ & Accounting Business, Cost Accounting, Financial Accounting \\
\hline 2. & Advance Course & $\begin{array}{l}\text { Accounting For Govermental And Non-Profit Organizations, Computerized } \\
\text { Accounting, Consolidate Financial Statement, Data Analysis, International } \\
\text { Accounting, Management Accounting, Taxation, Toal Quality Management }\end{array}$ \\
\hline 3. & $\begin{array}{l}\text { Economic, Financial } \\
\text { Course Theoretical }\end{array}$ & $\begin{array}{l}\text { Business Organisation And Administration, E-Commerce, Financial Management, } \\
\text { Human Resource Management, International Economic Relation, Macroeconomic, } \\
\text { Marketing, Microeconomic, Money, Banking And Finance }\end{array}$ \\
\hline 4. & General Course & $\begin{array}{l}\text { Research, Statistics, Civil And Commercial Law, Foreign Language, Labor Law And } \\
\text { Social Security, Management Information System, Mathematics For Economics, } \\
\text { Quantitative Methods For Finance }\end{array}$ \\
\hline 5. & Basic Required Skills & $\begin{array}{l}\text { Adaptive, Communication, Creativity, Critical Thinking, Entrepreneurial Skills, } \\
\text { Teamwork Skills }\end{array}$ \\
\hline
\end{tabular}

Hasil dari pengelompokkan di atas digunakan sebagai kode dalam melakukan coding pada kurikulum akuntansi perguruan tinggi. Setelah dilakukan coding, selanjutnya dilakukan pengecekan terhadap keberadaan kode dalam kurikulum akuntansi seluruh perguruan tinggi. Pengecekan ini dilakukan dengan menggunakan fitur text search. Hasil yang didapatkan dari text search kemudian di-export ke dalam microsoft excel. Berikutnya hasil perhitungan disatukan dan dilanjutkan dengan perhitungan jumlah mata kuliah yang ada dalam masing-masing kelompok. Setelah dilakukan perhitungan secara keseluruhan untuk kompetensi yang menjadi harapan user, pengolahan data dilanjutkan dengan metode statistik melalui program SPSS.

\section{Hasil penelitian}

Berdasarkan analisis yang telah dilakukan pada data kurikulum dan kompetensi, dapat diketahui keberadaan masing-masing kompetensi dalam kurikulum akuntansi. Berikut penulis uraikan temuan penelitian terkait dengan kurikulum akuntansi dan kesesuaiannya dengan kompetensi yang diharapkan 
Kurikulum akuntansi pada perguruan tinggi di Amerika, Eropa, Asia dan Australia

Setelah dilakukan analisis konten terhadap kurikulum akuntansi perguruan tinggi, didapatkan hasil berupa perhitungan keberadaan suatu mata kuliah dan kompetensi pada kurikulum akuntansi. Hasil analisis konten yang didapatkan, kemudian dilanjutkan dengan perhitungan statistik. Hasil perhitungan statistik kurikulum akuntansi terdiri dari empat kelompok, seperti yang terdapat pada tabel berikut ini.

Tabel 1. Hasil Statistik Kelompok Mata Kuliah

\begin{tabular}{|l|l|c|c|}
\hline \multicolumn{3}{|c|}{ Descriptive Statistics } \\
\hline No & \multicolumn{1}{|c|}{ Kelompok } & N & Mean \\
\hline 1 & Accounting Core & 60 & 0,87 \\
\hline 2 & Business Core & 60 & 0,79 \\
\hline 3 & General Course & 60 & 0,41 \\
\hline 4 & Other Course & 60 & 0,31 \\
\hline
\end{tabular}

Sumber: Olahan data (2021)

Berdasarkan tabel di atas dapat dilihat bahwa rata-rata keberadaan mata kuliah yang termasuk dalam kelompok accounting core memiliki nilai paling besar, yakni 0,87. Hal ini berarti bahwa pada kurikulum akuntansi, rata-rata $87 \%$ perguruan tinggi mengutamakan mata kuliah yang berfokus pada bidang akuntansi. Kelompok business core juga memiliki rata-rata yang cukup besar, yakni sebesar 0,79. Hal ini berarti bahwa selain kompetensi akuntansi, perguruan tinggi juga mementingkan keberadaan mata kuliah dalam bidang bisnis dalam kurikulum akuntansi mereka. Kemudian keberadaan mata kuliah di bidang umum memiliki rata-rata sebesar 0,41 serta mata kuliah lainnya yang dapat mendukung perkembangan karir lulusan sebesar 0,31. Berdasarkan hasil temuan di atas, dapat diketahui bahwa dalam membentuk lulusan yang berkompeten, perguruan tinggi menyusun kurikulum akuntansi dengan mengarahkan lulusan untuk memiliki kompetensi di bidang akuntansi, bisnis, kompetensi umum dan kompetensi lainnya yang dapat mendukung karir lulusan .

Jika dilihat dari masing-masing wilayah, perguruan tinggi juga memiliki fokus yang berbeda dalam membentuk kompetensi lulusannya. Berikut disajikan tabel hasil identifikasi muatan kurikulum akuntansi berdasarkan wilayah masing-masing perguruan tinggi.

Tabel 2. Hasil Statistik Kelompok Mata Kuliah Pada Masing-Masing Wilayah

\begin{tabular}{|l|l|r|r|r|r|r|r|r|r|}
\hline \multirow{2}{*}{ No } & \multirow{2}{*}{ Kelompok } & \multicolumn{2}{|c|}{ Amerika } & \multicolumn{2}{c|}{ Eropa } & \multicolumn{2}{c|}{ Asia } & \multicolumn{2}{c|}{ Australia } \\
\cline { 3 - 11 } & & N & Mean & N & Mean & N & Mean & N & Mean \\
\hline 1 & Accounting Core & 25 & 0,92 & 12 & 0,75 & 12 & 0,83 & 11 & 0,94 \\
\hline 2 & Business Core & 25 & 0,72 & 12 & 0,82 & 12 & 0,95 & 11 & 0,76 \\
\hline 3 & General Course & 25 & 0,33 & 12 & 0,50 & 12 & 0,58 & 11 & 0,29 \\
\hline 4 & Other Course & 25 & 0,27 & 12 & 0,37 & 12 & 0,38 & 11 & 0,27 \\
\hline \multicolumn{4}{c}{ Sumber: Olahan data (2021) } \\
\hline
\end{tabular}


Pada tabel di atas dapat dilihat bahwa rata-rata perguruan tinggi di Amerika dan Australia memiliki fokus utama pada kompetensi akuntansi dalam menghasilkan lulusan yang berkompeten. Sedangkan, rata-rata perguruan tinggi di Eropa dan Asia berfokus pada kompetensi bisnis dalam menghasilkan lulusan yang berkompeten. Namun, perbedaan nilai antara accounting core dengan business core pada masingmasing wilayah tidak terlalu jauh. Hal ini berarti bahwa perguruan tinggi membekali lulusannya dengan kompetensi akuntansi dan bisnis secara beriringan, yang juga diikuti dengan kompetensi umum dan lainnya.

Dalam penelitian ini, penulis juga menemukan beberapa perguruan tinggi telah memasukkan mata kuliah yang berkaitan dengan teknologi digital dalam kurikulumnya. Seperti yang diketahui, pada saat ini perkembangan teknologi telah membawa pengaruh pada tren dalam dunia bisnis dan keuangan. Perguruan tinggi dituntut untuk mampu memberikan kurikulum yang dapat memperkuat kompetensi lulusan untuk merespon secara memadai kebutuhan modern. Dengan keberadaan mata kuliah yang berkaitan dengan teknologi digital ini menunjukkan bahwa beberapa perguruan tinggi telah merespon dengan baik perubahan yang ada. Mata kuliah tersebut diantaranya adalah technology in accounting (33 perguruan tinggi), enterprise resource planning/ERP (5 perguruan tinggi), blockchain (3 perguruan tinggi), dan digital business (13 perguruan tinggi).

\section{Kesesuaian kompetensi lulusan akuntansi dengan standar KKNI, organisasi profesi dan harapan user}

\section{KKNI}

Melalui analisis konten yang dilakukan terhadap muatan kurikulum akuntansi dengan standar kompetensi KKNI, dapat diketahui jumlah keberadaan masing-masing kompetensi dalam kurikulum akuntansi. Untuk melihat tingkat kesesuaian antara kurikulum akuntansi dengan standar kompetensi, penulis melakukan analisis statistik desktiptif pada hasil analisis konten yang telah didapatkan sehingga diperoleh hasil seperti yang terlihat pada tabel berikut ini.

Tabel 3. Hasil Statistik Kesesuaian Kurikulum Dengan Standar Kompetensi
\begin{tabular}{|l|c|c|}
\hline \multicolumn{3}{|c|}{ Descriptive Statistics } \\
\hline & N & Mean \\
\hline KKNI & 60 & 0,55 \\
\hline Kompetensi Organisasi Profesi & 60 & 0,43 \\
\hline Kompetensi Harapan Users & 60 & 0,41 \\
\hline
\end{tabular} Sumber: Olahan data (2021)

Dari tabel di atas dapat dilihat bahwa mean (rata-rata) kesesuian antara kompetensi lulusan yang dinilai berdasarkan kurikulum akuntansi perguruan tinggi dengan standar kompetensi lulusan berdasarkan KKNI adalah sebesar 0,55 atau 55\%. Hal ini berarti bahwa pada kurikulum akuntansi, perguruan tinggi rata-rata telah memuat 55\% standar kompetensi KKNI. Ini menunjukkan relavansi yang cukup besar 
jika dibandingkan dengan rata-rata kesesuian kompetensi lulusan akuntansi dengan kompetensi berdasarkan organisasi profesi $(0,43$ atau $43 \%)$ dan harapan user $(0,41$ atau 41\%). Angka tersebut didapat dengan melakukan pemeriksaan kompetensi terhadap muatan kurikulum akuntansi perguruan tinggi.

Kesesuaian standar kompetensi dengan kurikulum akuntansi pada masingmasing wilayah memiliki perbedaan nilai, seperti yang dapat diihat pada tabel berikut ini.

Tabel 4. Hasil Statistik Kesesuaian Standar Kompetensi Pada Masing-Masing Wilayah

\begin{tabular}{|c|c|c|c|c|c|c|c|c|c|}
\hline \multirow{2}{*}{ No } & \multirow{2}{*}{ Standar Kompetensi } & \multicolumn{2}{|c|}{ Amerika } & \multicolumn{2}{|c|}{ Eropa } & \multicolumn{2}{|c|}{ Asia } & \multicolumn{2}{|c|}{ Australia } \\
\hline & & $\mathbf{N}$ & Mean & $\mathbf{N}$ & Mean & $\mathrm{N}$ & Mean & $\mathrm{N}$ & Mean \\
\hline 1 & KKNI & 25 & 0,47 & 12 & 0,62 & 12 & 0,71 & 11 & 0,50 \\
\hline 2 & Organisasi Profesi & 25 & 0,42 & 12 & 0,41 & 12 & 0,48 & 11 & 0,42 \\
\hline 3 & Harapan User & 25 & 0,39 & 12 & 0,41 & 12 & 0,48 & 11 & 0,36 \\
\hline
\end{tabular}

Dari tabel di atas dapat dilihat bahwa kurikulum akuntansi perguruant tinggi yang berada di wilayah Asia memiliki nilai mean (rata-rata) terbesar, yakni $71 \%$. Kemudian diikuti dengan perguruan tinggi yang berada di Eropa, Australia dan Amerika, yakni sebesar 62\%, 50\%, dan 47\%. Hal ini menunjukkan bahwa kurikulum akuntansi perguruan tinggi yang berada di Asia lebih sesuai dengan standar kompetensi KKNI, di mana standar tersebut juga berasal dari Asia (Indonesia). Dari hasil yang didapat dapat dilihat bahwa tidak hanya dengan kurikulum perguruan tinggi di Asia, namun juga memiliki kesesuaian yang cukup besar degan kurikulum akuntansi perguruan tinggi yang berada di Eropa dan Australia.

Berdasarkan analisis yang dilakukan juga dapat dilihat keberadaan masingmasing parameter atau substansi pokok lulusan KKNI pada kurikulum akuntansi perguruan tinggi. Berikut merupakan hasil yang didapatkan. 


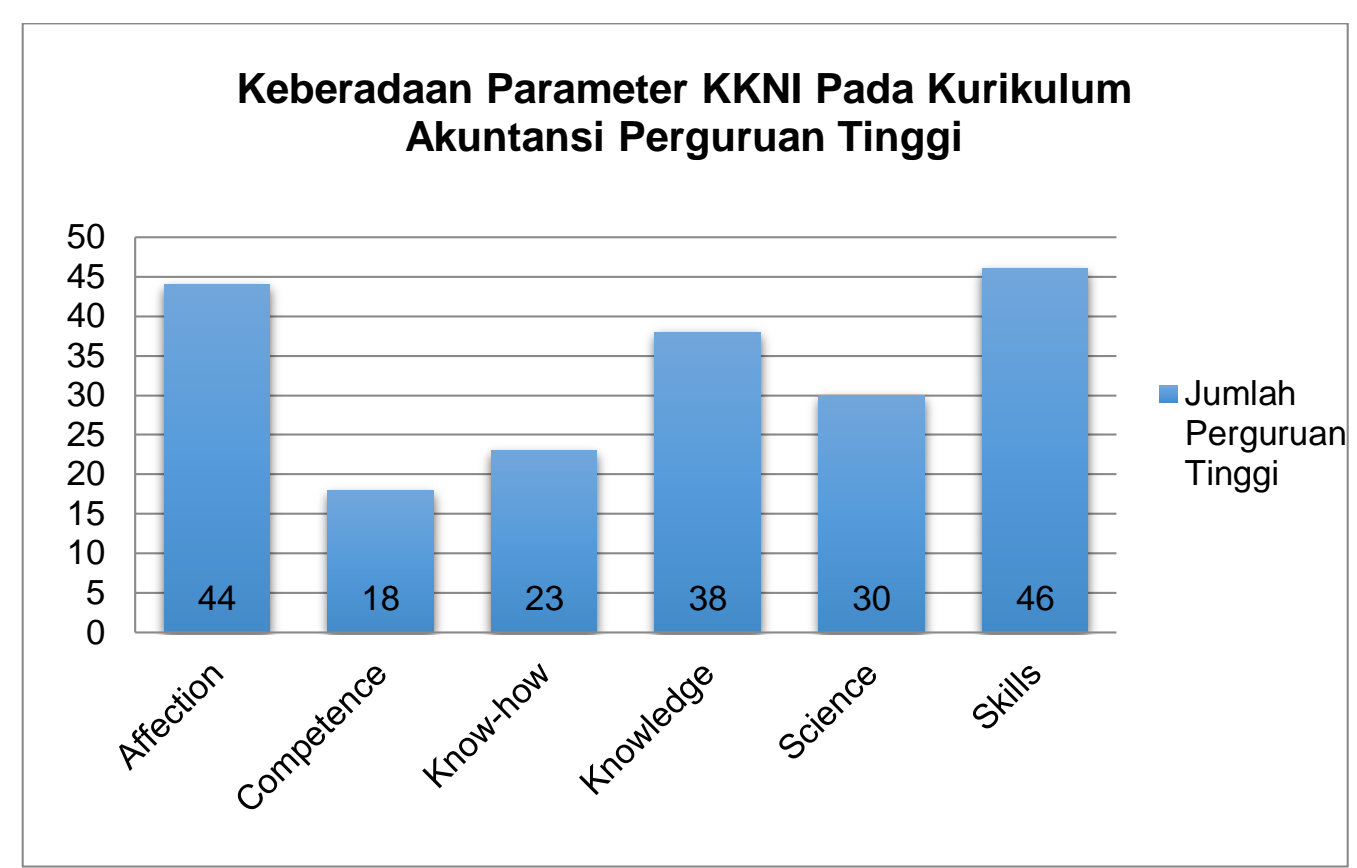

Gambar 2. Keberadaan parameter KKNI pada kurikulum akuntansi perguruan tinggi

Dari grafik dapat diketahui bahwa pada kurikulum akuntansi perguruan tinggi, parameter yang paling banyak dimuat adalah skills. Ini menunjukkan bahwa perguruan tinggi tidak hanya mementingkan pengetahuan, namun juga keterampilan dalam membentuk kompetensi lulusannya.

\section{Organisasi profesi}

Melalui analisis konten yang dilakukan terhadap muatan kurikulum akuntansi dengan kompetensi berdasarkan kerangka kerja organisasi profesi, dapat diketahui jumlah keberadaan masing-masing kompetensi dalam kurikulum akuntansi. Untuk melihat tingkat kesesuaian antara kurikulum akuntansi dengan kompetensi organisasi profesi, dilakukan analisis statistik desktiptif sehingga diperoleh hasil seperti yang terlihat pada tabel 3 Hasil Statistik Kurikulum Dengan Standar Kompetensi. Berdasarkan tabel tersebut, dapat diketahui mean (rata-rata) kesesuaian kurikulum akuntansi perguruan tinggi dengan kompetensi organisasi profesi adalah sebesar 0,43 atau 43\%. Hal ini menunjukkan bahwa rata-rata $43 \%$ kurikulum akuntansi perguruan tinggi telah sesuai dengan kompetensi organisasi profesi.

Kesesuaian antara kompetensi organisasi profesi dengan kurikulum akuntansi juga dapat dilihat pada masing-masing wilayah, seperti yang dapat dilihat pada tabel 4Hasil Statistik Kesesuaian Standar Kompetensi Pada Masing-Masing Wilayah. Dari tabel tersebut dapat dilihat bahwa kurikulum akuntansi perguruan tinggi yang berada di wilayah Asia memiliki nilai mean (rata-rata) terbesar, yakni 48\%. Kemudian diikuti dengan perguruan tinggi yang berada di Amerika, Australia dan Eropa, yakni sebesar $42 \%, 42 \%$, dan 41\%. Hal ini menunjukkan bahwa kurikulum akuntansi perguruan tinggi dari keempat wilayah memiliki nilai mean yang tidak jauh berbeda. Nilai mean dari keempat wilayah masih berada di bawah 50\%.

Selain mean keseluruhan dan masing-masing wilayah, juga dapat dilihat ratarata masing-masing kelompok yang terdapat pada kompetensi organisasi profesi seperti yang terlihat pada tabel berikut ini. 
Tabel 5. Hasil Statistik Kesesuaian Kurikulum Dengan Kelompok Kompetensi Organisasi

Profesi

\begin{tabular}{|l|c|l|}
\hline \multicolumn{3}{|c|}{ Descriptive Statistics } \\
\hline & N & Mean \\
\hline Accounting Competencies & 60 & 0,72 \\
\hline Business Competencies & 60 & 0,40 \\
\hline Digital Skills & 60 & 0,17 \\
\hline Professional Competencies & 60 & 0,43 \\
\hline
\end{tabular}

Sumber: Olahan data (2021)

Dari tabel di atas dapat dilihat bahwa pada kurikulum akuntansi perguruan tinggi, keberadaan kompetensi akuntansi memiliki nilai yang lebih besar daripada kelompok lainnya, yakni sebesar sebesar 0,72 atau 72\%. Kesesuaian accounting competencies dengan kurikulum akuntansi yang dilihat dari keberadaan mata kuliah yang membentuk nilai mean kompetensi akuntansi. Hal ini berarti bahwa keberadaan mata kuliah di bidang akuntansi menjadi fokus utama perguruan tinggi untuk membentuk kompetensi lulusan.

Setelah accounting competencies, nilai mean yang terbesar kedua adalah professional competencies. Kesesuaian kompetensi profesional dengan kurikulum akuntansi adalah sebesar 0,43 atau 43\%. Kemudian diikuti dengan kompetensi bisnis dan keterampilan digital yakni sebesar $40 \%$ dan 17\%. Ketiga kompetensi ini memiliki nilai mean di bawah 50\%, hal ini berarti perguruan tinggi harus mempertimbangkan untuk lebih meningkatkan lagi keberadaan mata kuliah yang dapat meningkatkan kompetensi lulusan dengan kemampuan prefesional, bisnis dan keterampilan digital seperti yang terdapat pada kompetensi organisasi profesi.

Dari hasil yang didapatkan dari analisis terhadap kesesuaian antara kompetensi lulusan akuntansi dengan kompetensi organisasi profesi, kurikulum akuntansi perguruan tinggi harus mempertimbangkan untuk melakukan peningkatan kesesuaian kurikulum mereka dengan kompetensi organisasi profesi. Dengan dilakukannya peningkatan terhadap kesesuaian kurikulum akuntansi dengan kompetensi organisasi profesi, diharapkan dapat membantu lulusan untuk dapat mempersiapkan diri dengan kompetensi yang dibekali perguruan tinggi untuk berkarir dalam profesi akuntansi.

\section{Harapan user}

Melalui analisis konten yang dilakukan terhadap muatan kurikulum akuntansi dengan kompetensi yang diperlukan user (harapan user), dapat diketahui jumlah keberadaan masing-masing kompetensi dalam kurikulum akuntansi. Untuk melihat tingkat kesesuaian antara kurikulum akuntansi dengan kompetensi harapan user, dilakukan analisis statistik desktiptif sehingga diperoleh hasil seperti yang terlihat pada tabel 3. Pada tabel tersebut dapat dilihat bahwa nilai mean harapan user merupakan nilai terendah diantara dua standar kompetensi lainnya, yakni sebesar 0,41 atau 41\%. Hal ini menunjukkan bahwa rata-rata $41 \%$ kurikulum akuntansi perguruan tinggi telah sesuai dengan kompetensi dibutuhkan dunia kerja (harapan user).

Kesesuaian antara kompetensi harapan user dengan kurikulum akuntansi juga dapat dilihat pada masing-masing wilayah, seperti yang dapat dilihat pada tabel 4. Dari 
tabel tersebut dapat dilihat bahwa kurikulum akuntansi perguruan tinggi yang berada di wilayah Asia memiliki nilai mean (rata-rata) terbesar, yakni 48\%. Kemudian diikuti dengan perguruan tinggi yang berada di Eropa, Amerika, dan Australia yakni sebesar 41\%, 39\%, dan 36\%. Hasil yang didapat ini menunjukkan bahwa kurikulum akuntansi perguruan tinggi dari keempat wilayah memiliki nilai mean yang berada di bawah 50\%. Ini menunjukkan bahwa kurikulum akuntansi perguruan tinggi masih perlu melakukan penyesuaian dan peningkatan agar dapat menghasilkan lulusan yang memiliki kompetensi yang diharapkan oleh user/pemberi kerja.

Selain mean keseluruhan dan masing-masing wilayah, juga dapat dilihat ratarata masing-masing kelompok yang terdapat pada kompetensi harapan user seperti yang terlihat pada tabel berikut ini.

Tabel 6. Hasil Statistik Kesesuaian Kurikulum Dengan Kelompok Kompetensi Harapan User

\begin{tabular}{|l|l|l|}
\hline \multicolumn{3}{|c|}{ Descriptive Statistics } \\
\hline & N & Mean \\
\hline Basic Accounting Course & 60 & 0,52 \\
\hline Advance Course & 60 & 0,38 \\
\hline Economic, Financial and Theoritical Course & 60 & 0,38 \\
\hline General Course & 60 & 0,42 \\
\hline Basic Required Skills & 60 & 0,34 \\
\hline
\end{tabular}

Sumber: Olahan data (2021)

Berdasarkan tabel di atas, dapat dilihat bahwa rata-rata basic accounting couse memiliki kesesuaian yang cukup besar yakni sebesar $52 \%$. Kemudian diikuti dengan general course yang memiliki nilai mean sebesar 42\%. Advance course dan Economic, financial and theoretical course memiliki nilai mean sebesar 38\%. Hasil mean terendah dari lima kompetensi harapan user adalah kelompok basic required skills, yakni sebesar 34\%. Dari hasil mean yang didapat ini, diketahui bahwa satu dari lima kelompok kompetensi harapan user telah memiliki kesesuaian kurikulum akuntansi dengan kompetensi harapan user lebih dari 50\%. Namun, empat kelompok lainnya memiliki kesesuaian antara kurikulum akuntansi dengan harapan user di bawah 50\%. Ini berarti bahwa pada bidang atau kelompok akuntansi, perguruan tinggi telah menyediakan mata kuliah yang sangat sesuai dengan kompetensi dasar akuntansi yang menjadi harapan user.

Hasil kesesuaian rata-rata kompetensi harapan user dan kesesuaian masingmasing kelompok, kurikulum akuntansi masih perlu penyesuaian dan penyelarasan terhadap kompetensi yang menjadi harapan user. Semakin tinggi kesesuaian antara kurikulum akuntansi dengan kompetensi yang menjadi harapan user akan memungkinkan terjadinya peningkatan kemampuan kerja lulusan. Jika dilihat pada kompetensi lulusan akuntansi perguruan tinggi, mereka lebih menekankan pada kompetensi dasar atau kompetensi teknis akuntansi, sedangkan user mengharapkan lulusan yang dapat memiliki kompetensi dalam beberapa bidang, seperti kompetensi bisnis, ekonomi dan keuangan, serta basic required skills. 


\section{Simpulan dan saran}

Analisis yang dilakukan pada kurikulum akuntansi dapat memberikan gambaran bagaimana kurikulum akuntansi perguruan tinggi dalam menghasilkan lulusan yang kompeten dan kesesuaiannya dengan standar kompetensi KKNI, kompetensi yang diperlukan untuk mempersiapkan lulusan masuk ke dalam profesi akuntansi dan kompetensi-kompetensi yang menjadi harapan user (pemberi kerja). Berdasarkan hasil penelitian, dalam membentuk lulusan yang kompeten, perguruan tinggi menyusun kurikulum akuntansi dengan mengarahkan lulusan untuk memiliki kemampuan di bidang akuntansi, bisnis, kemampuan umum dan kemampuan lainnya yang dapat mendukung karir lulusan. Rata-rata perguruan tinggi di Amerika dan Australia memiliki fokus pada kelompok mata kuliah akuntansi, sedangkan rata-rata perguruan tinggi di Eropa dan Asia memiliki fokus pada kelompok mata kuliah bisnis. Beberapa perguruan tinggi telah memasukkan mata kuliah yang berkaitan dengan teknologi digital maupun mata kuliah khusus dalam kurikulumnya.

Dari kesesuaian antara kompetensi lulusan akuntansi dengan standar KKNI sudah cukup sesuai, sedangkan antara kompetensi lulusan akuntansi dengan kompetensi organisasi profesi dan kompetensi harapan user belum cukup sesuai. Kurikulum akuntansi perguruan tinggi yang berada di Asia rata-rata sudah sesuai dengan standar kompetensi KKNI, sedangkan kurikulum akuntansi perguruan tinggi yang berada di Eropa, Australia dan Amerika sudah cukup sesuai. Parameter KKNI yang paling banyak dimuat dalam kurikulum akuntansi perguruan tinggi adalah skills dan affection.

Kesesuaian kompetensi lulusan akuntansi dengan kompetensi organisasi profesi pada kelompok accounting competencies sudah cukup sesuai, sedangkan pada kelompok professional competencies dan business competencies masih belum sesuai, namun pada kelompok digital skill masih kurang sesuai (rata-rata kesesuaian rendah). Kesesuaian antara kompetensi lulusan akuntansi dengan kompetensi harapan user pada kelompok basic accounting course sudah sesuai, namun advance course, economic, financial and theoretical course, general course, dan basic required skills masih belum sesuai (rata-rata kesesuaian rendah).

Semakin tinggi kesesuaian antara kurikulum akuntansi dengan ketiga standar kompetensi akan memungkinkan terjadinya peningkatan kemampuan kerja lulusan. Untuk itu, diharapkan adanya harmonisasi dan penyesuaian lanjutan antara kurikulum akuntansi dengan standar kompetensi lulusan guna meningkatkan kompetensi lulusan akuntansi. Di samping itu, penelitian ini memiliki kontribusi teoritis berupa penjelasan mengenai bagaimana kurikulum akuntansi dari perguruan tinggi yang berasal dari berbagai wilayah dalam menghasilkan lulusan yang kompeten serta kesesuaiannya dengan standar kompetensi KKNI, organisasi profesi dan harapan user. Hasil penelitian ini juga dapat menjadi pertimbangan dan masukan dalam perbaikan dan pengembangan kurikulum akuntansi di masa yang akan datang.

Dari penelitian yang dilakukan, adapun saran yang diberikan adalah sebagai berikut.

1. Perguruan tinggi diharapkan untuk dapat meningkatkan kesesuaian kurikulum mereka dengan kompetensi organisasi profesi dan kompetensi harapan user. Hal ini dikarenakan dengan semakin sesuainya kurikulum akuntansi perguruan tinggi 
dengan ketiga standar kompetensi, maka akan semakin meningkatkan kompetensi yang dimiliki lulusan.

2. Perguruan tinggi yang belum memuat mata kuliah yang berkaitan dengan teknologi digital sebaiknya dapat mengadopsi atau memuat mata kuliah-mata kuliah tersebut dalam kurikulumnya, agar dapat menghasilkan lulusan yang memiliki kemampuan yang lebih beragam.

Penelitian dalam bidang kurikulum akuntansi dan kesesuaiannya dengan standar kompetensi lulusan memiliki cakupan yang luas untuk diteliti. Penelitian yang dilakukan menggunakan analisis konten dan analisis statistik deskriptif terhadap enam puluh kurikulum akuntansi perguruan tinggi merupakan salah satu bentuk pemeriksaan terhadap muatan kurikulum akuntansi. Untuk penelitian selanjutnya, dapat dilakukan dengan menggunakan metode lain, memperluas cakupan sampel penelitian ataupun dengan menambah sumber data dari kerangka kerja organisasi profesi dan update kompetensi-kompetensi yang menjadi harapan user. Selain itu, penelitian selanjutnya juga dapat mempertimbangkan penggunaan body of knowledge sebagai dasar dalam melakukan pengelompokkan mata kuliah pada kurikulum akuntansi perguruan tinggi.

\section{Batasan penelitian}

Adapun beberapa batasan penelitian dari penelitian ini adalah sebagai berikut.

1. Perbedaan informasi mengenai kurikulum yang diperoleh dari website resmi masing-masing perguruan tinggi. Tidak semua perguruan tinggi menyajikan informasi kurikulum akuntansi mereka secara detail. Hal ini mengakibatkan keterbatasan informasi yang diperoleh.

2. Kerangka kerja organisasi profesi yang digunakan. Pada penelitian ini hanya menggunakan 4 kerangka kerja organisasi profesi dalam melihat kompetensi dari organisasi profesi, yakni kerangka kerja dari AICPA, IFAC, CIMA dan CA ANZ.

3. Pengelompokkan yang terdapat dalam kurikulum akuntansi perguruan tinggi. Dalam melihat bagaimana kurikulum akuntansi perguruan tinggi menghasilkan lulusan yang kompeten, peneliti melakukan pengelompokkan mata kuliah yang didasarkan pada kesamaan fokus dan tujuan dari masing-masing mata kuliah.

\section{Referensi}

[1] Adkins, D. A., Geddie, M. F., Moore, P. H., \& Griffin, R. B. (2014). Analysis of 2014's Thirty Best Undergraduate Accounting Programs. Journal of Academic Administration in Higher Education, 12(1), 49-60.

[2] AICPA. (2006). Reference guide The AICPA Pre-certification Core Competency Framework Accounting competencies Business competencies Professional. https://www.aicpa.org/interestareas/accountingeducation/resources/corecom petency.html\%0A\%0A

[3] Andre, S. M., \& Smith, B. L. (2014). Enhancing the undergraduate accounting 
curriculum to augment core competencies. Advances in Accounting Education: Teaching and Curriculum Innovations, 15, 59-78. https://doi.org/10.1108/S1085462220140000015002

[4] Bui, B., \& Porter, B. (2010). The expectation-performance gap in accounting education: An exploratory study. Accounting Education, 19(1-2), 23-50. https://doi.org/10.1080/09639280902875556

[5] CA ANZ. (2020). The Chartered Accountants Australia and New Zealand Capability Model. $\quad$ https://www.charteredaccountantsanz.com/learning-andevents/learning/capability-model

[6] CIMA. (2019). CGMA Competency Framework 2019 Update. https://www.cgma.org/resources/tools/cgma-competency-framework.html

[7] Cobbin, P. E., \& Lee, R. E. N. (2002). A Micro-Level Approach to Internationalising the Accounting Curriculum. Journal of Studies in International Education, 6(1), 5977. https://doi.org/10.1177/1028315302006001005

[8] Creswell, J. W. (2007). Qualitative enquiry \& research design, choosing among five approaches. In Book: Vol. 2nd ed.

[9] Flinders, D. J., \& Thornton, S. J. (2004). The Curriculum Studies Reader (2nd ed).

[10] Hasan, S.H. (1988). Evaluasi Kurikulum. Jakarta: Proyek Pengembangan Lembaga Pendidikan Tenaga Kependidikan

[11] IAESB, I. A. E. S. B. (2017). International Accounting Education Standards Board TM Handbook of International Education Pronouncements 20 s17 Edition. https://www.ifac.org/system/files/publications/files/2017-Handbook-ofInternational-Education-Pronouncements.PDF

[12] Institute of Chartered Accountants of England and Wales (ICAEW), Education and Training Committee. (1996). Added Value Professionals: Chartered Accountants in England and Wales 2005. London: ICAEW.

[13] Jackson, D. (2009b), “An international profile of industry-relevant competencies and skill gaps in modern graduates", International Journal of Management Education, Vol. 8 No. 1, pp. 29-58.

[14] Lawson, R. A., Blocher, E. J., Brewer, P. C., Cokins, G., Sorensen, J. E., Stout, D. E., Sundem, G. L., Wolcott, S. K., \& Wouters, M. J. F. (2014). Focusing accounting curricula on students' long-run careers: Recommendations for an integrated competency-based framework for accounting education. Issues in Accounting Education, 29(2), 295-317. https://doi.org/10.2308/iace-50673

[15] Low, M., Botes, V., Rue, D. Dela, \& Allen, J. (2016). Accounting Employers ' 
Expectations - The Ideal Accounting Graduates. E-Journal of Business Education \& Scholarship of Teaching, 10(1), 36-57.

[16] Mandilas, A., Kourtidis, D., \& Petasakis, Y. (2014). Accounting curriculum and market needs. Education and Training, 56, 776-794. https://doi.org/10.1108/ET12-2013-0138

[17] Moore, P. H., \& Griffin, R. B. (2017). Evaluation of the 2014 Best Undergraduate Accounting Programs as Compared to the 2004 Top Undergraduate Accounting Programs. Journal of Academic Administration in Higher Education, 13(1), 7-18. http://ezproxy.lib.uconn.edu/login?url=https://search.ebscohost.com/login.asp

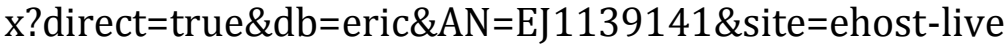

[18] Natoli, R., Jackling, B., Kaider, F., \& Clark, C. (2013). Mapping WIL activities in the curriculum to develop graduate capabilities: A case study in accounting. AsiaPacific Journal of Cooperative Education, 14(2), 75-88.

[19] Peraturan Menteri Pendidikan dan Kebudayaan No. 73 Tahun 2013. Penerapan Kerangka Kualifikasi Nasional Bidang Pendidikan Tinggi. Jakarta

[20] Ramadan, S. (1992). Practitioners view to analyze content level of undergraduate acc.pdf (p. Vol 8, No. 3, 1992, PP. 9-25).

[21] Sekaran, U., \& Bougie, R. (2011). Research Methods for Business: A Skill-Building Approach, 6th Edition.

[22] Sugiyono. (2013). Metode Penelitian Kuantitatif, Kualitatif, dan R\&D. Alfabeta.

[23] Undang-undang No. 20 Tahun 2003. Sistem Pendidikan Nasional. Jakarta 